\title{
Academics and Athletics: A Part and Apart in the American Campus
}

\author{
John R. Thelin \\ University of Kentucky
}

Some time ago a newspaper reporter asked a professor if he thought ignorance and apathy about intercollegiate athletics were troubling. The professor replied, "I don't know and I don't care." Well, at least this candid answer reinforced and anticipated some of the findings of the recent Knight Commission Study directed by my respected long time colleague, Prof. Janet Lawrence of the University of Michigan (Lawrence, Hendricks, \& Ott, 2007). My plea bargain is that you do not automatically include me in this general finding. As for me, when it comes to college sports, I do care. I hardly know all the answers or the questions. But I have spent almost four decades involved in college sports, either as a student-athlete, as a scholar, or as one involved in governance and policy. My essay is intended to suggest some historical and institutional context as signs of the depth and endurance of my own commitment to informed concern about the vitality and health of intercollegiate athletics as part of sound higher education mission and values.

The historical premise is that both academics and athletics are part of the American campus. Yet they are often apart from one another, with each operating in distinctive orbits and by different codes. Given these contrasts, I want to look at some research that has provided useful insights on how intercollegiate sports fit into higher education. Good, serious writing about college sports requires careful sifting and sorting that avoids two polarities in the popular media: on the one hand, exaggerated praise and celebration versus, on the other hand, the numerous sensational exposes and allegations of excess and abuse.

Here are some of my favorite examples of the two extremes. The melodrama of scandal and expose includes Win at Any Cost: The Sell Out of College Athletics (Dealy, 1990), Unsportsmanlike Conduct: Exploiting College Athletes (Byers, 1995), A Payroll to Meet: A Story of Greed, Corruption \& Football at SMU (Whitford, 1989), and Down and Dirty: The Life and Crimes of Oklahoma Football (Thompson \& Sonnenschein, 1990) It's a truism that you cannot judge a book by looking at its cover, and I find this caution to be sound advice in making sense out of the sensationalist exposes. For example, Down and Dirty has two pictures on its cover: one of a student-athlete wearing the Oklahoma Sooners' white and red jersey; the other, the same young man in an orange jump suit. My first impression was that perhaps he had transferred to rival Oklahoma State University, whose colors are

The author is with the Department of Educational Policy Studies and Evaluation, University of Kentucky, Lexington, KY. 
orange and black. On closer inspection, it was the blaze orange of the prison system uniforms. Well, no problem; I try to find something positive in any situation and figured either way, it shows that there can be good articulation transfer arrangements among all state institutions, whether penal or educational in mission.

To another extreme, some years ago Strode Books and a number of other commercial publishers churned out a line of glossy books with abundant photographs celebrating various campuses' sports glory. The list includes works about the Nittany Lions (Rappoport, 1973), Kentucky Basketball's Big Blue Machine (Rice, 1987), Hook 'Em Horns (Freeman, 1974), and so on. Most of the volumes were written by Sports Information Directors or local sports writers. My favorite title was Bow Down to Washington (Rockne, 1975). I mistakenly thought it was about lobbyists paying homage to federal government agencies in the District of Columbia. In fact, it was a tribute to the University of Washington Huskies. One hagiography of a legendary coach was We Believe . . Bear Bryant's Boys Talk. (Bynum, with Brondfield, 1980). That title was magnetic; I was curious to see whether Bear's Boys could write, as well as talk. The publisher was "The We Believe Trust Fund at the Bank of A\&M" and the "Republic of Texas." The Republic of Texas, as I recall, was a renegade political group that printed its own currency and declared its own sovereignty. Whew! I wonder if their electoral districts included Tuscaloosa, Alabama as a colony.

I try to steer through this emotional and conflicting literature at the same time I try to make sense out of my home turf-namely, the American college and university. My main resolution is that the Department of Intercollegiate Athletics stands out as higher education's "Peculiar Institution." Yes, it is part of the campus. However, its conduct and facilities suggest that it enjoys the benefits of a special zoning ordinance within the campus. To draw from Murray Sperber's organizational analyses, college sports as the Peculiar Institution asks for and receives entitlements and privileges seldom received by other units (Sperber, 1990).

For example, last year our Provost sent out to all academic deans, chairs, and faculty a memo reminding us in no uncertain terms about the ten required steps in undertaking any faculty appointment, ranging from visiting assistant professors to endowed full professorships. The regulations were strict and confining. And, whether by accident or design, they took a great deal of faculty committee time, meetings with the Human Resources Department, and compliance with internal and federal procedure. This meant it consumed substantial calendar time. Little wonder that academic appointments are not made hastily.

In contrast, one finds that major coaching vacancies at many universities are filled promptly. In late November the football coach at the University of Arkansas who announced his retirement on Monday had been hired by the University of Mississippi by Tuesday (Associated Press, 2007). A few weeks later the University of Mississippi announced that Houston McNutt's brother had been hired as Assistant Athletics Director. This is a marvel of American efficiency and decisiveness. But it is an option not available to an academic department.

It's not uncommon to read in newspaper sports sections matter-of-fact announcement that a high profile coach has on his staff a son or other relative. Most interesting is what I call the monarchial succession, whereby university officials announce well ahead of time that a head coach has named his successorsometimes a son-who will become head coach the following season. If there were 
the proverbial level playing field, this would mean that the department chair of, let's say, the history department could bequeath a professorship to her daughter. Yet this would be unlikely and outrageous - as one recalls the intricate and strict 10-point requirements set forth by the provost.

From time to time there are highly ritualized gestures of cooperation across zones. For example, a head coach may say that, "After all, I too am a teacher." This conjures images of professors and coaches joining to put their shoulders to the wheel to educate undergraduates. But wait! My historical research has uncovered an important exception to the proclamation. Consider the case of Henry "Red" Sanders, who was appointed head football coach at UCLA and built the young program into a national powerhouse. When wooed by Texas A\&M to leave UCLA, one Los Angeles sportswriter commented, "It was very tempting, but Sanders cared about more than material goods." Another Los Angeles sportswriter wrote, "He was the greatest coach, teacher and leader of men I have ever known." Elsewhere, a large news photo of Sanders hard at work had the caption, "Red Sanders Doing What He Loved Best-Teaching." Between 1950 and 1954 he was selected as national football coach of the year and at the local, civic level was the Los Angeles Citizen of the Year and a keynote speaker at the Eagle Scouts awards banquet (Van Leuven, 1982, chs. 6, 7).

The flip side of this praise was that Coach Sanders had been an embarrassment and a problem to the UCLA Chancellor for several years. His public misbehavior included excessive drinking and philandering-behaviors which he flaunted. It led the UCLA administration to attempt to renegotiate the terms of his contract. Sanders successfully deflected this on the grounds that he was employed by the ASUCLA (Associated Students of UCLA) not by the University. Finally, the Chancellor sought the opinion of the State Attorney General who ruled, "We consider a college athletic coach to be in the same category as a teacher." (Cunningham, 1957). Sanders' attorney countered that a college coach was not a teacher-thus, could not be required to the code of conduct expected of a teacher. The dispute never went to trial because Sanders died in August 1958 when, after a preseason football practice he suffered a heart attack in a downtown hotel while celebrating with company and without his shirt in a manner that I doubt would have won him a second citizenship award from the Los Angeles Boy Scouts council (Springer and Arkush, 1991, p.104).

Most important for my analysis is that the awards and latitude afforded a winning coach once again illustrates that is the zoning ordinance of allowable conduct which separates intercollegiate sports from other citizens and units in the academic city-state. Whether these exceptions and privileges are good or bad I leave as a topic for our discussion. I do observe that the differences are great and undeniable.

Once in a while I have come across extraordinary examples of academic-athletic cooperation in unexpected situations. In September 1991 an article in the Washington Post reported that the University of Michigan had used a federal research grant to cover some travel and entertainment expenses for its contingent to attend the Rose Bowl game in Pasadena. The incident, which led to an investigation on research propriety by a House of Representatives Subcommittee, perhaps gave some optimism that high-powered research and high-powered intercollegiate athletics could help one another-although, in this case, the intercollegiate athletics program seems to have received the better part of the deal. (Cooper, 1991). 
One of the highly ritualized complaints about the NCAA among disgruntled coaches and athletic directors is that well-intentioned intercollegiate athletics programs are often hamstrung by inordinate regulations. The customary visual ploy is to lift up the current NCAA handbook - which, evidently, rivals the federal budget or the New York City telephone book in girth and number of pages-and to ask rhetorically, "Who is responsible for this?" The usual suspects to round up are the alleged meddlesome professors, or, perhaps, a zealous rule-oriented NCAA staff. Were I the Czar of American higher education, I would release these suspects on their own recognizance. Rather, the culprits are found often within the fellowship of coaches and athletic directors themselves. In large, faculty do not involve themselves in pushing for drafting regulations-or enforcing them. Most often the complaints and whistle blowing often do come from coaches and athletic directors who feel that coaches and athletic directors elsewhere have gained an unfair advantage.

All this makes sense to me. Some years ago I read a wonderful book by Ronald Smith called Sports and Freedom (Smith, 1988). In his historical account of the early decades of college sports, he looked at the relations between the university teams from Oxford and Cambridge in England who often competed against varsity squads from Harvard, Yale, and Princeton. Whether in crew or in track and field, Smith reconstructed the view from 1900 that the university student-athletes from England tended to adhere to the spirit of the law in sportsmanship, whereas the American student-athletes followed the letter of the law, often at the expense of violating the spirit of the law (Smith).

And that legacy persists well into the 21 st century. Whether in NCAA Division I, Division II, or Division III, whatever the restrictions and codes are, one can be certain that some coaches and teams will push to the edge. To paraphrase legendary major league baseball player Pete Rose, "If I was a bettin' man," I would say that some coaches and athletic directors will bend if not break the laws. And, to confirm historian Ronald Smith, it's evidently all right to disobey the spirit so long as you abide by the technical letter of the law. Oh, what a shameless allegation, right? Well, here's a headline from a 2002 article that proclaimed, "U of L Plans to Build Basketball Team Dorm."

The University of Louisville Athletics Association approved its share of a proposal to build a \$4.5 million dormitory for men's basketball players and other students. The association will pay the rent on the dorm rooms, its only role in the construction of the proposed 32,000 square-foot, two-story building.

An unnamed donor has pledged an undisclosed amount to finance construction. ... If the board of trustees approves the project next week, the University will lease the land to a developer. (Associated Press, 2002)

Now, of course, journalists and headline writers often skip over important details. Worth noting is the concluding paragraph, "The dorm would house 35 students, more than half of whom would have to be non-scholarship athletes, according to NCAA rules" (Associated Press, 2002).

To lapse into sports talk, one could say "No harm, no foul!" But really, who are we kidding? It is a varsity basketball dorm. Complying with the NCAA regulation is readily done by including student managers, token "regular" students, et al. 
If there is an engraved plaque for such projects, I suggest it would be "With a Wink and a Nod-and Full Funding."

My examples of special zoning ordinances on hiring coaches, on building varsity athletic dorms are, of course, isolated. But that is to be illustrative and brief. Give me time and space, and I will continue the litany of examples. Perhaps the rebuttal from coaches and athletics is, "But this is different." I agree. First, to quote the Roman maxim, "The exception makes the rule." And, second, I would conclude and emphasize that, yes, intercollegiate athletics is different.

Little wonder, then, that many, perhaps most, professors are indifferent or neutral to and/or disconnected from the practices and policies of college sports. Who as a professor has the time, energy or inclination to question or probe? I'm sure the athletic department practices are justifiable and technically correct. So, what's the big deal? And that question is also the answer as to why there is ignorance and apathy about the genuine workings of college sports. Professors often don't know and don't care or, rather, have ceased to try to know and to care in any enduring way. The Department of Athletics, usually with tacit or direct affirmation from the central administration, and certainly from the Board of Trustees and the Athletic Association, has neatly crafted a good arrangement. And, to be sure, faculty organizations have in some cases adopted a strict constructionist approach in which they formally vote to exclude themselves and their faculty senates from jurisdiction over intercollegiate athletics.

For example, in 1976 at one flagship state university, a professor filed a resolution with the University Senate expressing concern that the university had proposed use of a "voluntary donation fund" for "allocating choice seating for University sporting events that was in direct conflict with and reflected unfavorably upon the fundamental academic role of the University" (Marsden, 1976). At the next meeting the Senate Council responded with the following recommendations: "The Governing Regulations clearly specify that the functions of the Senate include only matters that are pertinent to academic issues. . . . We believe this policy of restraint should be maintained, and we do not believe that the proposed resolution deals with a topic that is within the scope of traditional and proper Senate concerns." (University of Kentucky Senate Council, 1976). Athletics, according to this logic, was not connected to educational issues, and the University's Faculty Senate opted not to pursue involvement in such matters. It was no less than Opportunity Lost.

Faculty retreat and restraint from intercollegiate athletics may be optional or discretionary. The imperative of Presidential involvement is quite another matter. I wish to direct our attention to an interesting, recent development in discussion of the governance of intercollegiate athletics. In 1990 the Knight Foundation's first report on intercollegiate athletics emphasized that colleges and universities adopt what was called the "One-plus-Three" model. (Knight Foundation Commission on Intercollgiate Athletics, 1991) What this meant was that the campus president was the "One" and was to be the leader of the three-part pursuit of academic integrity, financial integrity, and athletic program certification. This sounded good. However, for the 21 st century, I suggest an amendment. Instead of relying so heavily on college and university presidents, I propose we put substantial and increasing focus and responsibility on another constituency: Boards of Trustees.

I make this amendment because a great number of articles about higher education emphasize the plight of the president and the unrealistic demands for them in 
any number of matters, including influence over major sports donors, booster clubs, and so on. Why not share the pain by having boards carry a burden commensurate with their powers? Boards of trustees are to me the paradox and chameleon of American higher education. They are invested with great power yet are among the least accountable and least scrutinized segments within college and university governance. Notice how most of our attention, including mine, is directed to such constituencies as coaches, athletic directors, presidents, and faculty. Perhaps one residual of our gathering today will be attempts to bring trustees into the forum and into the spotlight.

Another reason for my suggestion is that college and university presidents have seldom shown much collective will or agreement on intercollegiate athletics issues. One reason we are here at this conference in 2008 is that more than a half century ago college presidents were sharply divided on the governance of college sports. During the years 1951-1952 the United States Congress appealed to the American Council of Education to bring together presidents from institutions nationwide to become the unified body to oversee college sports-a role Congress did not relish assuming. Discussions among the presidents at the ACE meetings were more fractured and rambling than, well, an English department faculty meeting. Negotiations broke off and led Congress to seek out a relatively small, lean organization based in Chicago - the National Collegiate Athletic Association-to step into the breach and take on primary responsibilities the presidents and the ACE could not or would not accept. (American Council on Education, February 16, 1952; Thelin, 1994, ch. 4)

In my proposal to shift responsibility from campus presidents to their boards of trustees, I have rediscovered a useful guide written in 1989 by the then President of New York University, L. Jay Oliva. It was published by the AGB, an acronym often mistaken for the sinister police force of the old Soviet Union. But that is the KGB. My concern is with the Association of Governing Boards. President Oliva's 33-page book was a model and marvel of brevity and utility entitled, What Trustees Should Know About Intercollegiate Athletics (Oliva, 1989). It provides insights and standards by which to look at such dimensions as recruitment, admissions, and the campus life of student-athletes. It includes chapters on "Your institutions and Its Competition." My favorite is its guide to "Athletic Oversight and the Role of Money." And, although it and many publications give primary attention to the NCAA Division I programs, Oliva explicitly includes a chapter, "A Special Message to Division III."

Because Oliva's guide focused on Boards of Trustees as its audience, it unwittingly missed what may be the governing body most tied to intercollegiate sports. The important supplement is that at many institutions, especially large state universities, there is an added, influential and almost invisible layer of governance: the board of the Athletic Association. Athletic Associations fascinate me because they provide yet another example of my theme of special zoning ordinances. They are the chameleons of higher education because, when convenient, they project themselves in the colors and hues of a private corporation-hence, shielded from some open records laws and accountability. At other times, they proclaim their stature as part of the public or state university-convenient when facing law suits and liability. They are, in my opinion, the tail that wags the dog, certainly of intercollegiate athletics and, in some instances, of the whole university. 
In an era when regional accreditation agencies emphasize the importance that presidents and academic officials have "institutional control" over myriad educational and extracurricular programs, the corporations of athletic associations taunt and tempt the letter and spirit of such codes.

The formation of incorporated athletic associations in the 1930s and 1940s has a mixed legacy. On the one hand, they signaled a reform and clarification of higher education funding. If, according to conference or NCAA rules, a varsity sports program is supposed to be self-supporting and excluded from drawing resources from the academic or general fund, the athletic association provided a firewall to help enforce that. And, at the same time, it provided a means for dynamic fund raising and athletic donor support.

Less sanguine to me is their allowance and encouragement of some other practices. The athletic corporation allows coaches and athletic directors to be hired (and fired) not as university staff but as employees of the Association. This was how my own university managed to hire Coach Paul Bryant in the late 1940s, which, ahem, technically meant that a coach was not a state employee or even a state university employee, but hired and paid by the athletic association corporation. In a similar vein, I recall basketball coach Jim Valvano taunting North Carolina State University administrators and faculty by reminding them, "You can't fire me! I'm an employee of the Wolfpack Association.” (Golenbock,1989). Very clever, indeed!

These structures and machinations are ingenious, disingenuous, and, over the course of a professor's career, predictable and then, ultimately, boring. The athletics department, with the support of its association, the board of trustees, and the president, has won. The zoning ordinances are strong. Those professors and presidents and provosts who choose to challenge the zoning ordinances would do well to seek permission (paying logo copyright royalties, of course, to Dartmouth College) to embrace the historic motto, "A Voice Cries Out in the Wilderness." But, one asks, "Why bother? Who is listening?"

What issue might be appropriate for university boards of trustees and athletic association boards to address? I think some policy matters associated with tax laws are good candidates. In recent months there has been a spirited forum on tax exemptions for college-sports donors, stimulated by John Lombardi's op-ed piece, "Taxing the Sports Factory." (Lombardi, 2007) President Lombardi has made a strong argument that this initiative is misplaced energy, which, if successful, would provide little assistance to reforming college sports. Fair enough. My suggestion is to focus on another tax issue that puts colleges and universities, not college-sports donors, at center stage. In particular, I wish to see resurrected a question that has surfaced from time to time over the past 20 years: Namely, how are athletic programs required to deal with "UBIT," that is, "unrelated business income tax." At the level of local government, municipalities and counties increasingly ask why campus lands and facilities not used for educational purposes should be tax exempt. (Blumenstyk, 1988). The issue is especially acute in college towns in which the college or university is a large land owner and property owner-and where propertytax exemption has a direct impact on public-school funding. Is a college football stadium or a golf course truly an "educational" facility for instructional, research, or service missions (Kirby, 1988)? At the federal level from the IRS, the question is less on property taxes and more on income and expenditures of programs and events (Jaschik, 1995). Why, for example, is an athletics association tax exempt 
for "educational" activities? This focus does not penalize donors, nor does it drag university presidents and board members into the quagmire of alumni and booster philanthropy. It does prompt university officials to provide a fresh explanation about the nuances and complexities of intercollegiate sports as part of their educational mission-hardly a trifling matter. It calls for no less than a "new deal" in dissecting and rethinking the 21 st century campus as a complex entity.

The complaint that college and university presidents have tended to be compliant or acquiescent about educational propriety and integration of college sports is not completely fair because, I think, it is incomplete. We each have our heroes in higher education. Mine included such presidents as Robert Atwell and William Bowen. My list is short and limited-I welcome your nominations. I submit that my slate is distinctive in that they know and care about college sports.

Atwell, who left the presidency of Pitzer College in California to be Vice President of the American Council on Education, relied on his academic training as an economist to provide fellow presidents and other higher education leaders with remarkable and readable studies of tracking and segments within college sports. His 1979 book, The Money Game, provided an early alert to the financial crises that most college sports programs faced, or soon would face-a development pretty much overlooked by sportswriters nationwide. He also mapped out the intercollegiate athletics terrain by identifying what he called the "semi-pro" funding model, most characteristic today of NCAA Division IA programs (Atwell, Grimes, and Lopiano, 1980)

Most recently, and familiar to many of you, is the systematic scholarship of William F. Bowen and his coauthors James Shulman and Sarah Levin at The Mellon Foundation. Over the past decade his two books-The Game of Life and Reclaiming the Game-have taken discussion of college athletics as part of the college experience beyond polemics into some tough-minded and sophisticated statistical analyses and interpretations. (Shulman and Bowen, 2001; Bowen and Levin, 2003). Most refreshing is Bowen's effectiveness in going beyond the conventional focus on the programs at the high-profile NCAA Division I-A institutions, as well as his focus on the distinctive practices and problems in Division I-AA and Division III. Although Bowen's studies, sponsored by the Mellon Foundation, are the most systematic and most widely disseminated, they are not alone. Indeed, the seminal article on the problems distinctive to Division III sports program's is Alan Draper's concise and insightful piece, "Innocence Lost: Division III Sports Programs," published in Change magazine (Draper, 1996). Draper's article, along with Bowen's studies, have at very least prompted us to recognize that with Division III there are "troubles in paradise."

The role of a Bob Atwell or a Bill Bowen as analyst and advocate of reform is not an easy one. What they do represent is a high point of serious, systematic research on college sports that has been percolating over the past two or three decades. The significance and urgency of their research are enhanced by their proven record as college and university presidents and academic leaders. In addition to the authors and works I've already cited, some of my favorite recent works include economist Andrew Zimbalist's Unpaid Professionals, in which he systematically examines commercialism in big-time college sports (Zimbalist, 1999). The most original portion of his work is his close analysis of the ritualized claim that the high salary of big-time college coaches are indelibly set by "market forces." 
Whether the findings of such authors elicit agreement or disagreement, they deserve our attention. I'm an historian, but I do not write for historians. The audience I hope to reach is that of higher education officials and leaders, ranging from presidents and provosts to athletic directors, board members, and conference commissioners. I do not have much use for writings about college sport that are either pedantic or polemic. What remains most elusive to me is gaining a sense of how presidents, provosts, athletic directors, coaches, and trustees acquire interpretations and rethink policies and practices.

My preference is for informed discussion from a variety of perspectives. In addition, I think - as befits a teacher-that educational priorities should provide the gyroscope for our colleges and universities. Despite that preference and wish, I doubt they will prevail. My estimate is that the mounting economic and financial crises within intercollegiate athletics departments and within total college and university operations, not educational values, will prompt substantial changes in the policies and practices of intercollegiate athletics. The paradox of the early $21 \mathrm{st}$ century is that intercollegiate athletics enjoys unparalleled power and prestige at all levels, yet at the same time, when only about 22 out of over 130 NCAA Division IA programs are financially self-supporting, tensions and problems will only increase. At such flash points I hope that good writing and research will be part of the realizations and resolutions. In conclusion, I think it will be the budget that is the most philosophical of documents in the future of intercollegiate athletics.

\section{References}

American Council on Education. (February 16, 1952). Report of the special committee on athletics policy. Washington, D.C.: American Council on Education.

Associated Press (June 22, 2002). "U of L plans to build basketball dorm," Lexington (KY) Herald-Leader. p. D6.

Associated Press (November 27, 2007) “Houston Nutt hired as Ole Miss coach.”. Lexington (KY) Herald-Leader.

Atwell, R.H., Grimes, B., \& Lopiano, D.A. (1980). The money game: Financing collegiate athletics. Washington, D.C.: American Council on Education.

Blumenstyk, G. (1988). Town-Gown battles escalate as beleaguered cities assail college tax exemptions. The Chronicle of Higher Education, 34(42), A1.

Bowen, W.G., \& Levin, S.A. (2003). Reclaiming the game: College sports and educational values. Princeton, Oxford: Princeton University.

Byers, W., with Hammer, C. (1995) Unsportsmanlike conduct: Exploiting college athletes. Ann Arbor: University of Michigan.

Bynum, M., with Brondfield, J. (1980) We believe . . Bear Bryant's boys talk. College Station, Texas: We Believe Trust Fund at the Bank of A\&M of the Republic of Texas.

Cooper, K.J. (September 11, 1991) "Rose Bowl expenses billed as research costs: University of Michigan charges questioned," Washington Post, A21.

Cunningham, T.J. (June 11, 1957) General Counsel of the University of California Regents to Chancellor Allen, RE: Sanders Problem (UCLA Archives).

Dealy, F.X., Jr. (1990). Win at any cost: The sell out of college athletics. New York: Carol. Draper, A. (1996). Innocence lost: Division III sports programs. Change, 28(6), 46-49.

Freeman, D.H. (1974). Hook 'em horns: A story of Texas football. Tomball, Texas: Strode. Golenbock, P. (1989). Personal fouls: The broken promises and shattered dreams of big money basketball at Jim Valvano's North Carolina State. New York: Penguin. 
Jaschik, S. (1995). Extensive IRS audits find many colleges are violating tax law. The Chronicle of Higher Education, 41(3), A28.

Kirby, D.J. (March/April 1988) "The carrier dome controversy: Rewriting the town-gown relationship," Change, 42-49.

Knight Foundation Commission on Intercollegiate Athletics. (1991). keeping faith with the student-athlete: a new model for intercollegiate athletics. Miami, Florida: Knight Foundation.

Lawrence, J. H., Hendricks, L.A., \& Ott, M. (October 15, 2007) Faculty perceptions of intercollegiate athletics survey: A study of faculty at NCAA Division I football bowl subdivision institutions. Washington, D.C.: Knight Commission on Intercollegiate Athletics.

Lombardi, J.V. (October 1, 2007) "Taxing the sports factory," Inside Higher Ed.

Marsden, J. (March 2, 1976). Resolution. Minutes of the University Senate. Lexington, Kentucky: University of Kentucky.

Oliva, L.J. (1989). What trustees should know about intercollegiate athletics. Washington, D.C.: AGB Special Report, Association of Governing Boards.

Rappoport, R. (1973). The Nittany lions: A story of Penn State football. Tomball, Texas: Strode.

Rice, R. (1987). Kentucky basketball's big blue machine. Tomball, Texas: Strode.

Rockne, D. (1975). Bow down to Washington: A story of Husky football. Huntsville, Alabama: Strode.

Shulman, J., \& Bowen, W.G. (2001). The game of life: College sports and educational values. Princeton and Oxford: Princeton University.

Smith, R. (1988). Sports and freedom: The rise of big-time college athletics. New York and Oxford: Oxford University.

Sperber, M. (1990). College sports, inc.: The athletic department vs. the university. New York: Henry Holt.

Springer, S., \& Arkush, M. (1991). Sixty years of USC-UCLA football. Stamford, Connecticut: Longmeadow.

Thelin, J.R. (1994). Games colleges play. Baltimore and London: Johns Hopkins University.

Thompson, C., \& Sonnenschein, A. (1990). Down and dirty: The life and crimes of Oklahoma football. New York: Carroll and Graf.

University of Kentucky Senate Council. (April 12, 1976). Minutes of the university senate. Lexington, Kentucky: University of Kentucky Senate.

Van Leuven, H. (1982). Touchdown UCLA: The bruin football story. Tomball, Texas: Strode.

Whitford, D. (1989). A payroll to meet: A story of greed, corruption \& football at SMU. New York: MacMillan.

Zimbalist, A. (1999). Unpaid professionals: Commercialism and conflict in big-time college sports. Princeton, New Jersey: Princeton University. 